\title{
JOB RELEVANT INFORMATION DESENTRALISASI DAN PARTISIPASI ANGGARAN TERHADAP KINERJA MANAJERIAL
}

\author{
Jasintha Dessy Tapatfeto \\ jasintha09@yahoo.com \\ Department of Accounting, State Polytechnic of Kupang, NTT
}

\begin{abstract}
This study aimed to examine the effect of budget participation on managerial performance by using Job Relevant Information as an intervening variable and combined with decentralization as a moderating variable. The population in this study are all companies in various industries in East Java in 2013. Data were analyzed using path analysis models and Moderating Regression Analysis. Based on test results found that budgetary participation and Relevant Job Information influence on managerial performance as well as the budgetary participation influence the Job Relevant Information. This suggests that the high level of participation budgeting will improve managerial performance and with the availability of information relevant to the task of allowing subordinates to be able to exchange information with the boss, so as to create the budget process better and produce a more effective decisions on eventually will support the manager to get better performance. The results of further testing, found that decentralization does not moderate the effect of budget participation on managerial performance. This suggests that the higher delegation of authority granted to managers in their companies remain excluded and given responsibility for preparing the budget, this is due to the pressure from superiors (leaders).
\end{abstract}

Key words: job relevant information, decentralization, budgeting participation and managerial performance

\begin{abstract}
ABSTRAK
Penelitian ini bertujuan untuk menguji pengaruh partisipasi penyusunan anggaran terhadap kinerja manajerial dengan menggunakan Job Relevant Information sebagai variabel intervening dan dikombinasikan dengan variabel desentralisasi sebagai pemoderasi. Populasi dalam penelitian ini adalah seluruh perusahaan dalam berbagai industri di Jawa Timur pada tahun 2013. Teknik analisis data menggunakan model Path Analysis dan Moderating Regression Analysis. Berdasarkan hasil pengujian ditemukan bahwa partisipasi penyusunan anggaran dan Job Relevant Information berpengaruh terhadap kinerja manajerial demikian halnya juga dengan partisipasi penyusunan anggaran berpengaruh terhadap Job Relevant Information. Hal ini menunjukkan bahwa tingginya tingkat partisipasi penyusunan anggaran akan meningkatkan kinerja manajerial dan dengan adanya ketersediaan informasi yang relevan dengan tugas memungkinkan bawahan untuk dapat saling bertukar informasi dengan atasan, sehingga dapat menciptakan proses penyusunan anggaran yang lebih baik dan menghasilkan suatu keputusan yang lebih efektif yang pada akhirnya akan mendukung kinerja manajer menjadi lebih baik. Hasil pengujian selanjutnya, menemukan bahwa desentralisasi tidak memoderasi pengaruh partisipasi penyusunan anggaran terhadap kinerja manajerial. Hal ini menunjukkan bahwa semakin tinggi pendelegasian wewenang yang diberikan kepada para manajer dalam perusahaan mereka tetap tidak dilibatkan dan diberikan tanggungjawab dalam penyusunan anggaran, hal ini disebabkan karena adanya tekanan dari atasan (pimpinan).
\end{abstract}

Kata kunci: job relevant information, desentralisasi, partisipasi anggaran dan kinerja manajerial.

\section{PENDAHULUAN}

Perusahaan perlu menetapkan tujuan di dalam melakukan pengelolaan perusaha- an, kemudian membuat rencana kegiatan untuk mencapai tujuan dan sasaran tersebut. Salah satu unsur terpenting yang 
digunakan manajemen dalam perencanaan perusahaan adalah anggaran. Anggaran sebagai pedoman kerja dan sasaran yang ingin dicapai oleh suatu organisasi, selain itu anggaran juga dapat digunakan oleh manajemen sebagai alat bantu untuk mengetahui kinerja (performance) dan dapat memotivasi manajemen dalam upaya untuk mencapai kinerja yang lebih baik dimasa yang akan datang.

Kinerja adalah hasil atau tingkat keberhasilan seseorang secara keseluruhan selama periode tertentu didalam melaksanakan tugas. Peningkatan kinerja manajerial membutuhkan partisipasi aktif karyawan dalam setiap kegiatan operasi perusahaan melalui kecakapan dan informasi yang diberikan. Salah satu kegiatan perusahaan yang membutuhkan partisipasi aktif karyawan adalah penyusunan anggaran. Oleh karena itu manajemen perlu menyusun anggaran dengan baik karena anggaran merupakan gambaran perencanaaan seluruh aktivitas kegiatan operasional perusahaan.

Keberhasilan setiap penyusunan anggaran dapat ditentukan oleh cara penyusunan anggaran itu sendiri. Pendekatan yang digunakan dalam penelitian ini adalah pendekatan partisipatif (top down dan buttom up) yang mana pendekatan partisipatif ini melibatkan semua tingkatan manajemen untuk mengembangkan rencana anggaran. Perusahaan tentunya dapat menggabungkan dua pendekatan tersebut kedalam penyusunan anggaran sehingga proses persiapan anggaran menjadi lebih efektif. Efektifitas pelaksanaan anggaran akan terwujud sesuai dengan tujuan perusahaan, jika didukung oleh orang-orang yang ada di dalam organisasi. Keterlibatan orang-orang dalam organisasi untuk merancang anggaran merupakan salah satu bagian dari literatur akuntansi keperilakuan (behavioral accounting) yang mana membahas hubungan antara partisipasi penyusunan anggaran dengan kinerja manajerial.

Berkaitan hubungan antara partisipasi anggaran dengan kinerja manajerial, terdapat beberapa pembahasan hasil peneliti- an yang bervariasi dan tidak konsisten. Penelitian yang dilakukan oleh Rosidi (2000), Chong dan Chong (2002), Coryanata (2004), Yusfanigrum dan Ghozali (2005), Nor (2007), Rihardjo (2009), Indarto dan Ayu (2011), Gul et al., (1995), Kren (1992). Namun hasil penelitian Adi (2006) membuktikan bahwa partisipasi anggaran dan kinerja manajerial memiliki hubungan yang negatif artinya bahwa dengan adanya partisipasi tidak memberikan pengaruh terhadap kinerja.

Hasil penelitian yang masih menimbulkan perbedaan ini menarik untuk dikaji lebih lanjut dengan menggunakan pendekatan kontijensi (contingency theory). Teori kontijensi diperlukan dalam penelitian ini untuk mengevaluasi efektifitas penganggaran partisipatif terhadap kinerja manajerial (Rihardjo, 2009). Studi ini di maksudkan untuk memperjelas hubungan antara partisipasi penyusunan anggaran dengan kinerja manajerial, serta mencoba untuk mengembangkan teori berkaitan hubungan partisipasi penyusunan anggaran terhadap kinerja manajerial dengan mengkombinasikan job relevant information sebagai variabel intervening dan desentralisasi sebagai variabel moderating.

Penggunaan informasi yang berhubungan dengan tugas (Job Relevant Information) akan membantu bawahan dalam meningkatkan pilihan tindakan manajemen menjadi lebih baik. JRI merupakan informasi yang dapat membantu manajer dalam memilih tindakan yang terbaik melalui upaya yang diinformasikan berupa kondisi organisasi dilihat dari tingkat perekonomian, keuangan, pemasaran dan lainnya, sehingga tentunya sangat membantu memberikan pengetahuan yang lebih baik kepada manajer mengenai altenatif keputusan dan tindakan yang dibutuhkan untuk pencapaian kinerja dan tujuan organisasi. JRI dapat meningkatkan kinerja melalui pemberian perkiraan yang lebih akurat mengenai lingkungan sehingga dapat dipilih rangkaian tindakan efektif yang terbaik (Kren, 1992). 
Desentralisasi dalam organisasi berkaitan erat dengan struktur organisasi yang memberikan gambaran mengenai kekuasaan dalam suatu organisasi. Struktur organisasi memiliki peranan dalam mempengaruhi kinerja (efisiensi dan efektifitas) pada tingkat organisasi maupun tingkat sub unit karena adanya desentralisasi, kualitas pengambilan keputusan menjadi lebih baik dibandingkan sentralisasi, sebab para manajer lebih memahami kondisi unit yang dipimpinnya (Govindarajan dan Anthony, 2007). Dengan adanya pembagian kekuasaan yang terdesentralisasi, maka para manajer memiliki kesempatan untuk berpartisipasi secara aktif dalam proses penyusunan anggaran yang pada akhirnya akan memberikan dukungan motivasi kepada bawahan untuk meningkatkan kinerjanya.

Berdasarkan uraian diatas maka rumusan masalah dalam penelitian ini adalah: (1) Apakah partisipasi penyusunan anggaran berpengaruh terhadap kinerja manajerial?, (2) Apakah partisipasi penyusunan anggaran berpengaruh terhadap job relevant information?, (3) Apakah job relevant information berpengaruh terhadap kinerja manajerial? (4) Apakah desentralisasi memoderasi pengaruh antara partisipasi penyusunan anggaran dan kinerja manajerial?

Penelitian ini bertujuan untuk (1) menguji secara empiris pengaruh partisipasi penyusunan anggaran terhadap kinerja manajerial, (2) menguji secara empiris pengaruh partisipasi penyusunan anggaran terhadap job relevant information, (3) menguji secara empiris pengaruh job relevant information terhadap kinerja manajerial serta (4) menguji secara empiris pengaruh antara partisipasi penyusunan anggaran dan kinerja manajerial, yang dimoderasi oleh desentralisasi.

\section{TINJAUAN TEORETIS Konsep Partisipasi}

Partisipasi penganggaran merupakan proses yang menggambarkan individu- individu yang terlibat dalam penyusunan anggaran dan mempunyai pengaruh terhadap target anggaran sehingga pada akhir periode anggaran dan setelah dilakukan penilaian secara menyeluruh maka akan timbul tindakan berupa penghargaan (reward) atas pencapaian target anggaran tersebut ataupun sebaliknya sebagai hukuman (punishment) atas kegagalan pencapaian target yang sudah direncanakan.

Pendekatan yang digunakan dalam penelitian ini yaitu pendekatan partisipasi, yang mana pendekatan ini mengutamakan proses kerjasama dalam pengambilan keputusan. Agar pelaksanaan anggaran sesuai dengan apa yang telah ditentukan terlebih dahulu, maka keterlibatan dari pihak-pihak yang terkait tidak dapat dihindari lagi, dengan kata lain partisipasi dari bawahan ikut berperan dalam penyusunan anggaran ini (Riyadi, 2007). Dengan ikut serta berpartisipasi dalam penyusunan anggaran, para manajer juga akan lebih memahami masalah yang mungkin timbul pada saat pelaksanaan anggaran (Indarto dan Ayu, 2011). Partisipasi dapat dikatakan sebagai suatu proses pengambilan keputusan secara bersama oleh dua pihak atau lebih, sehingga hasil keputusan tersebut memiliki dampak di masa yang akan datang bagi para pembuat keputusan tersebut.

\section{Konsep Anggaran}

Anggaran dapat diartikan sebagai pedoman kerja dan sasaran yang ingin dicapai oleh suatu organisasi, selain itu anggaran juga dapat digunakan oleh manajemen sebagai alat bantu untuk mengetahui kinerja (performance) dan dapat memotivasi manajemen dalam upaya untuk mencapai kinerja yang lebih baik dimasa yang akan datang (Riharjo, 2009). Anggaran yang terlalu menekan, cenderung menimbulkan sikap agresif manajer tingkat bawah terhadap manajer tingkat atas yang kemudian dapat mengakibatkan inefisiensi dan penurunan kinerja.

Pada umumnya definisi anggaran memiliki 4 unsur (Wirjono dan Raharjono, 
2007), yaitu: 1) Rencana, anggaran merupakan rencana yang telah disusun untuk memberikan arah bagi perusahaan di masa yang akan datang. 2) Mencakup seluruh kegiatan perusahaan, yaitu semua kegiatan yang dilakukan oleh seluruh bagian yang ada dalam perusahaan. Anggaran berfungsi sebagai pedoman kerja sehingga harus mencakup seluruh kegiatan perusahaan. 3) Satuan moneter, anggaran dinyatakan dalam satuan unit moneter yang dapat diterapkan pada berbagai kegiatan perusahaan yang beraneka ragam. Satuan moneter berguna untuk menyeragamkan semua kegiatan perusahaan yang beraneka ragam sehingga mudah untuk diperbandingkan dan dianalisis. 4) Jangka waktu tertentu, anggaran disusun untuk jangka waktu tertentu yang akan datang sehingga memuat taksiran-taksiran tentang segala sesuatu yang akan terjadi dan akan dilakukan di masa mendatang.

Anggaran dapat digunakan untuk meningkatkan kualitas pengambilan keputusan yang mana dapat diketahui perkiraan pendapatan, biaya perbaikan, biaya perlengkapan, dan sebagainya sehingga perusahaan dapat menghindari pengeluaran biaya-biaya yang tidak diperlukan dan mengatasi pembelian yang tidak penting. Keputusan yang lebih baik tersebut dapat menghindari timbulnya masalah serta dapat menghasilkan kondisi keuangan yang lebih baik.

\section{Partisipasi Penyusunan Anggaran}

Partisipasi anggaran bertujuan untuk membentuk sikap, perilaku karyawan, dan manajer merasa memiliki dan menumbuhkan pengaruh motivasional terhadap tujuan anggaran. Para manajer departemen harus memiliki input yang penting dalam menganggarkan pendapatan dan biaya karena mereka terlibat langsung dan sangat memahami kegiatan departemen mereka. Anggaran yang disusun oleh karyawan harus dapat memberikan rekomendasi, merevisi angka-angka dalam anggaran bila diperlukan, dan menyetujui ataupun tidak menyetujui item-item yang utama (Apriwandi, 2012). Input karyawan sangat diperlukan karena mereka sangat memahami operasi perusahaan. Partisipasi dalam penganggaran merupakan faktor kritis yang dapat mempengaruhi keefektifan perusahaan secara keseluruhan.

Selain membentuk sikap dan perilaku, partisipasi anggaran juga sangat membantu manajer level atas untuk dapat mengkomunikasikan tujuan perusahaan pada semua manajer unit dibawahnya sehingga memudahkan pengkoordinasian kegiatan maupun evaluasi kinerja manajer tersebut. Melalui partisipasi dapat mendorong manajer untuk mengidentifikasi tujuan, menerimanya dengan suatu komitmen dan bekerja agar dapat mencapainya (Wentzel, 2002; Chong dan Chong, 2002). Pada dasarnya program anggaran akan lebih berhasil jika bawahan dilibatkan atau diperkenankan bertanggungjawab mengendalikan biaya dan menyusun anggaran untuk area pertanggungjawabannya.

\section{Konsep Kinerja}

Seseorang mempunyai prestasi tinggi apabila memiliki keinginan dan mampu berbuat lebih baik daripada yang lain. Kinerja (performance) merupakan gambaran mengenai tingkat pencapaian pelaksanaan suatu kegiatan atau program organisasi untuk pencapaian sasaran, tujuan, misi dan visi organisasi. Otley (1999) mendefinisikan kinerja sebagai acuan yang berkaitan erat dengan kegiatan melakukan pekerjaan, dalam hal ini meliputi hasil kerja yang dicapai.

Secara umum dapat dikatakan bahwa kinerja merupakan prestasi yang dapat dicapai oleh individu organisasi dalam periode tertentu. Kebutuhan berprestasi (sence of achievement) tersebut merupakan salah satu kebutuhan terkuat dalam diri manusia. Dalam kebutuhan ini manusia merasa apa yang menjadi pekerjaan penting sehingga akan menyelesaikan pekerjaan itu dengan lebih baik. 


\section{Kinerja Manajerial}

Seseorang dengan tingkat kepuasan kerja tinggi menunjukkan sikap yang positif terhadap apa yang dikerjakan. Kinerja manajerial merupakan suatu kondisi yang seharusnya diketahui dan diinformasikan kepada pihak-pihak tertentu untuk mengetahui seberapa jauh tingkat pencapaian hasil suatu organisasi, dihubungkan dengan tujuan organisasi yang bersangkutan serta mengetahui dampak positif dan negatif suatu kebijakan operasional yang ditetapkan dan digambarkan dalam Bahasa perencanaan yang disebut dengan anggaran (Rihardjo, 2009).

Kinerja manjerial merupakan bentuk kinerja para anggota individu dalam sebuah organisasi guna melaksanakan kegiatan manajerial seperti perencanaan, investigasi, koordinasi, supervisi, pemilihan staf, negosiasi dan perwakilan. Kinerja manajerial berperan sebagai faktor yang dapat meningkatkan keefektifan kinerja suatu organisasi (Puspaningsih, 2002). Tolak ukur keefektifan suatu organisasi dapat terlihat dari tercapainya tujuan anggaran dan bawahan mendapat kesempatan untuk terlibat atau berpartisipasi dalam proses penyusunan anggaran serta memotivasi bawahan untuk mengidentifikasi dan melakukan negosiasi dengan atasan mengenai target anggaran, menerima kesepakatan anggaran dan melaksanakannya.

\section{Job Relevant Information}

Ketersediaan informasi yang berhubungan dengan tugas akan meningkatkan perencanaan untuk mencapai tujuan yang ditetapkan, yang pada akhirnya akan meningkatkan kinerja. Terdapat dua keuntungan yang diperoleh dari adanya transfer informasi dari bawahan kepada atasan, yaitu atasan dapat mengembangkan strategi yang lebih baik yang dapat disampaikan kepada bawahan, sehingga kinerja akan meningkat (Himawan dan Ika, 2010).

Informasi yang berhubungan dengan tugas (Job Relevant Information) sebagai informasi yang memfasilitasi pembuatan keputusan manajerial. Penggunaan informasi yang berhubungan dengan tugas (JRI) akan membantu bawahan dalam meningkatkan pilihan tindakan manajemen menjadi lebih baik (Yusfaningrum dan Ghozali, 2005). Kren (1992) mendefinisikan job relevant information sebagai informasi yang tersedia bagi manajer untuk meningkatkan efektifitas keputusan yang berkaitan dengan tugas dan membantu manajer dalam memilih tindakan terbaik melalui informed effort yang lebih baik.

\section{Desentralisasi}

Desentralisasi dalam organisasi berkaitan erat dengan struktur organisasi yang memberikan gambaran mengenai kekuasaan dalam suatu organisasi. Struktur organisasi memiliki peranan dalam mempengaruhi kinerja (efisiensi dan efektifitas) pada tingkat organisasi maupun tingkat sub unit karena adanya desentralisasi, kualitas pengambilan keputusan menjadi lebih baik dibandingkan sentralisasi, sebab para manajer lebih memahami kondisi unit yang dipimpinnya (Govindarajan dan Anthony, 2007). Dengan struktur desentralisasi maka akan memberikan rasa tangungjawab yang lebih besar kepada para manajer dalam kegiatan perencanaan dan pengendalian, sehingga mereka membutuhkan kewenangan yang lebih besar bila dibandingkan dengan struktur sentralisasi.

\section{Hubungan Partisipasi Penyusunan Ang- garan dan Kinerja Manajerial}

Pendekatan yang digunakan dalam penelitian ini yaitu pendekatan partisipasi, yang mana pendekatan ini memungkinkan para manajer yang akan bertanggungjawab atas kinerja anggaran, untuk berpartisipasi dalam pengembangan anggaran dan menentukan besarnya anggaran. Program anggaran akan lebih berhasil jika bawahan dilibatkan atau diperkenankan bertanggung jawab mengendalikan biaya dan menyusun anggaran untuk area pertanggungjawabannya masing-masing. 
Setiap anggaran yang akan digunakan di periode mendatang didasarkan atas kinerja masa lalu yang berisi rencana strategis dalam pengambilan keputusan (McGill, 2001). Anggaran partisipatif selain digunakan sebagai pendekatan manajerial juga dapat digunakan untuk menilai seberapa jauh pencapaian kinerja seseorang. Anggaran partisipatif dapat dinilai sebagai pendekatan manajerial yang dapat meningkatkan kinerja setiap anggota organisasi sebagai individual karena dengan adanya partisipasi dalam penyusunan anggaran diharapkan setiap individu mampu meningkatkan kinerjanya sesuai dengan target yang telah ditetapkan sebelumnya (Sardjito dan Muthaher, 2007). Adapun dampak positif dari adanya partisipasi bawahan terhadap motivasi manajerial (Anthony dan Govindarajan, 2007) yaitu: 1) Kemungkinan ada penerimaan yang lebih besar atas cita-cita anggaran jika anggaran dipandang berada dalam kendali pribadi manajer, dibandingkan bila dipaksakan secara eksternal. Hal ini mengarah kepada komitmen pribadi yang lebih besar untuk mencapai cita-cita tersebut. 2) Hasil penyusunan anggaran partisipatif adalah pertukaran informasi yang efektif. Besar anggaran yang telah disetujui merupakan hasil dari keahlian dan pengetahuan pribadi dari pembuat anggaran, yang paling dekat dengan lingkungan produk/pasar.

Indarto dan Ayu (2011) membuktikan bahwa hubungan partisipasi anggaran terhadap kinerja manjerial positif signifikan. Hal ini sesuai dengan keadaan yang terjadi pada perusahaan besar di Jawa Tengah yang menerapkan manajer tingkat menengah (manajer fungsional) turut berperan aktif dalam penyusunan anggaran untuk meningkatkan kinerja manajerialnya. Selanjutnya penelitian yang dilakukan oleh Rosidi (2000) menemukan bahwa variabel partisipasi, komitmen dan job relevant information secara bersama-sama berpengaruh secara positif dan signifikan terhadap prestasi kerja yang mana menjelaskan bahwa kuatnya hubungan antara partisipasi dan pres- tasi karena adanya pengaruh tidak langsung yang positif dari commitment dan job relevant information. Hasil yang sama juga dibuktikan dengan penelitian Chong dan Chong (2002) yang menunjukkan bahwa partisipasi penyusunan anggaran mempengaruhi komitmen bawahan terhadap tujuan anggaran. Adanya pengaruh komitmen terhadap tujuan anggaran secara simultan akan menggerakkan pengaruh informasi kepada tingginya keterlibatan diri manajer tingkat bawah sehingga mereka akan meningkatkan usaha untuk mengumpulkan, menukarkan dan menggunakan JRI yang pada akhirnya akan meningkatkan kinerja mereka. Coryanata (2004) membuktikan bahwa hubungan antara partisipasi dalam penyusunan anggaran dan kinerja manajerial positif dan signifikan hanya pada pelimpahan wewenang yang terdesentralisasi serta interaksi komitmen organisasi yang tinggi. Selanjutnya Penelitian Yusfaningrum dan Ghozali (2005) menemukan bahwa partisipasi anggaran berpengaruh positif dan signifikan terhadap kinerja manajerial. Nor (2007) membuktikan bahwa partisipasi penyusunan anggaran berpengaruh positif signifikan terhadap kinerja manajerial, hal ini menunjukkan bahwa jika partisipasi dalam penyusunan anggaran tinggi maka kinerja manajerial akan meningkat. Penelitian Rihardjo (2009) membuktikan bahwa penganggaran partisipatif secara signifikan berpengaruh terhadap kinerja manajerial pada organisasi pemerintah daerah. Kren (1992) membuktikan bahwa partisipasi anggaran mempunyai hubungan positif dengan kinerja manajerial melalui job relevant information. Selanjutnya penelitian yang dilakukan oleh Gul et al., (1995) membuktikan bahwa organisasi dengan tingkat desentralisasi yang tinggi menunjukkan hubungan yang positif antara partisipasi anggaran dan kinerja manajerial dan pada tingkatnya yang rendah hubungannya adalah negatif.

Akan tetapi hasil penelitian Adi (2006) membuktikan bahwa hubungan partisipasi anggaran terhadap kinerja negatif, artinya 
bahwa proses penyusunan anggaran di pemerintah daerah di dinas pemerintahan Kota Surabaya dan Pemerintah Kabupaten Sidoarjo disusun oleh para kepala dinas dan kabag, hal ini disebabkan karena tidak adanya faktor internal dan eksternal dalam melibatkan kasubsi dan staf untuk menentukan dan menetapkan isi anggaran.

Berdasarkan penjelasan di atas, maka hipotesis yang dapat diajukan untuk menguji partisipasi penyusunan anggaran adalah: $\mathrm{H}_{1}$ : Partisipasi penyusunan anggaran berpengaruh positif terhadap kinerja manajerial.

\section{Hubungan Partisipasi dalam Penyusunan Anggaran dan Job Relevant Information}

Partisipasi dalam penyusunan anggaran mampu mengurangi ketimpangan informasi, dimana informasi yang dibutuhkan manajer adalah informasi yang relevan dengan bidang pekerjaaannya. Penggunaan informasi yang berhubungan dengan tugas (JRI) tentunya akan membantu bawahan/ pelaksana anggaran dalam meningkatkan pilihan tindakan manajemen yang lebih baik. Dengan Job Relevant Information tentunya mampu memberikan pemahaman yang lebih baik kepada manajer mengenai alternatif keputusan dan tindakan yang perlu diambil dalam proses penyusunan anggaran guna pencapaian tujuan (Kren, 1992).

Rosidi (2000) menguji partisipasi dalam penganggaran dan prestasi manajer: pengaruh komitmen organisasi dan informasi job-relevant. Sampel penelitian ini dilakukan kepada para manajer di perusahaan go public yang terdaftar pada BEJ dan BES (Indonesian Capital Market Directory). Hasil penelitiannya membuktikan bahwa variabel partisipasi dan job relevant information secara bersama-sama berpengaruh secara positif dan signifikan terhadap prestasi kerja yang mana menjelaskan bahwa kuatnya hubungan antara partisipasi dan prestasi karena adanya pengaruh tidak langsung yang positif dari job relevant information. Chong dan Chong (2002) menguji peran komitmen tujuan anggaran dan job relevant information (JRI) diantara hubungan partisipasi anggaran terhadap kinerja manajerial. Sampel yang diambil secara acak dari perusahaan manufaktur di Australia. Hasil Pengujian membuktikan bahwa partisipasi penyusunan anggaran mempengaruhi komitmen bawahan terhadap tujuan anggaran. Adanya pengaruh komitmen terhadap tujuan anggaran secara simultan akan menggerakkan pengaruh informasi kepada tingginya keterlibatan diri manajer tingkat bawah sehingga mereka akan meningkatkan usaha untuk mengumpulkan, menukarkan dan menggunakan Job Relevant Information yang pada akhirnya akan meningkatkan kinerja mereka. Yusfaningrum dan Ghozali (2005) menguji pengaruh partisipasi anggaran terhadap kinerja manajerial melalui komitmen tujuan anggaran dan Job Relevant Information sebagai variabel intervening. Penelitiannya berhasil membuktikan bahwa partisipasi berpengaruh positif dan signifikan terhadap job relevant information artinya bahwa dalam proses partisipasi, bawahan diberi kesempatan untuk memberikan masukan berupa informasi yang dimilikinya kepada atasan sehingga atasan akan memperoleh pemahaman yang lebih baik tentang pengetahuan yang relevan dengan tugas (task relevant knowledge). Indarto dan Ayu (2011) menguji pengaruh partisipasi dalam penyusunan anggaran terhadap kinerja manajerial perusahaan melalui kecukupan anggaran, komitmen organisasi, komitmen tujuan anggaran, dan Job Relevant Information. Hasil pengujian membuktikan bahwa partisipasi anggaran secara signifikan berhubungan dengan Job Relevant Information dan Job Relevant Information secara signifikan berhubungan dengan kinerja manajerial sehingga dapat dikatakan penelitian ini mendukung hipotesis alternatif (Ha) diterima. Kren (1992) menguji partisipasi anggaran dan kinerja manajerial: dampak informasi dan volatilitas lingkungan. Sampel Penelitian dilakukan kepada para manajer divisi dari 96 perusahaan manufaktur yang tercatat dalam Fortune 500. 
Hasil penelitiannya membuktikan bahwa Partisipasi anggaran mempunyai hubungan positif dengan kinerja manajerial melalui job relevant information, artinya bahwa partisipasi anggaran tidak berhubungan secara langsung dengan kinerja manajerial akan tetapi melalui JRI.

Untuk meneliti hubungan antara partisipasi penyusunan anggaran dan job relevant information diturunkan hipotesis sebagai berikut:

$\mathrm{H}_{2}$ : Partisipasi penyusunan anggaran berpengaruh positif terhadap job relevant information.

\section{Hubungan Job Relevant Information dan Kinerja Manajerial}

Tersedianya informasi yang berhubungan dengan tugas akan meningkatkan perencanaan untuk mencapai tujuan yang ditetapkan, yang pada akhirnya akan meningkatkan kinerja manajer. Partisipasi manajer dalam penyusunan anggaran akan meningkatkan usaha manajer untuk memprediksi lingkungan dan mengarahkan perhatian manajer pada keputusan dan perilaku yang diperlukan di masa yang akan datang (Indarto dan Ayu, 2011). Job Relevant Information dapat meningkatkan kinerja karena memberikan prediksi yang lebih akurat mengenai kondisi lingkungan dan memberikan seleksi yng efektif untuk melakukan tindakan terbaik. Job Relevant Information sangat dibutuhkan untuk mengambil langkah strategis dalam pencapaian tujuan yang telah ditetapkan (Kren,1992).

Rosidi (2000) menguji partisipasi dalam penganggaran dan prestasi manajer: pengaruh komitmen organisasi dan informasi Job-Relevant. Hasil penelitiannya membuktikan bahwa variabel partisipasi, job relevant information secara bersama-sama berpengaruh secara positif dan signifikan terhadap prestasi kerja yang mana menjelaskan bahwa kuatnya hubungan antara partisipasi dan prestasi karena adanya pengaruh tidak langsung yang positif dari job relevant information. Chong dan Chong (2002) menguji peran komitmen tujuan ang- garan dan job relevant information (JRI) diantara hubungan partisipasi anggaran terhadap kinerja manajerial. Sampel dilakukan pada manajer level menengah, yang diambil secara acak dari perusahaan manufaktur di Australia. Hasil penelitiannya membuktikan bahwa JRI dan kinerja manajerial berhubungan positif dan signifikan (path coefficient $=0,26, p<0,05$ ), hal ini menunjukkan bahwa ketika para karyawan menjalankan tujuan-tujuan anggaran maka mereka akan meningkatkan usaha untuk mengumpulkan dan menggunakan job relevant information yang akan memfasilitasi proses pembuatan keputusan sehingga tujuan anggaran bisa tercapai. Indarto dan Ayu (2011), menguji pengaruh partisipasi dalam penyusunan anggaran terhadap kinerja manajerial perusahaan melalui kecukupan anggaran, komitmen organisasi, komitmen tujuan anggaran, dan Job Relevant Information. Hasil pengujian menunjukkan bahwa partisipasi anggaran secara signifikan berhubungan dengan Job Relevant Information dan Job Relevant Information secara signifikan berhubungan dengan kinerja manajerial sehingga dapat dikatakan penelitian ini mendukung hipotesis alternatif (Ha) diterima.

Akan tetapi penelitian Yusfaningrum dan Ghozali (2005) yang menguji partisipasi terhadap kinerja melalui job relevant information, membuktikan bahwa partisipasi memiliki hubungan positif signifikan terhadap JRI namun JRI memiliki hubungan positif tidak signifikan terhadap kinerja.

Untuk meneliti hubungan antara job relevant information dan kinerja manajerial disusun hipotesis 3, yaitu:

$\mathrm{H}_{3}$ : Job relevant information berpengaruh secara positif terhadap kinerja manajerial.

\section{Hubungan Desentralisasi dan Kinerja Manajerial}

Desentralisasi dapat dikatakan sebagai bentuk penyebaran atau pelimpahan secara meluas mengenai kekuasaan dalam membuat keputusan bagi tingkatan-tingkatan 
manajer yang lebih rendah. Dimana struktur sentralisasi yang tinggi, sebagian keputusan diambil pada tingkat hirarki organisasi yang tertinggi, dan apabila sebagian otorisasi didelegasikan pada level yang rendah dalam organisasi, maka organisasi tersebut lebih desentralisasi.

Struktur organisasi desentralisasi secara umum ditujukan guna pengambilan keputusan yang terjadi dalam suatu organisasi. Struktur organisasi yang bersifat desentralisasi memberikan gambaran bahwa pimpinan puncak mendelegasikan wewenang dan pertanggungjawaban pada bawahannya dan bawahan tersebut diberi kekuasaan atau wewenang untuk membuat berbagai macam keputusan (Riyadi, 2007). Dengan adanya pembagian kekuasaan yang terdesentralisasi, maka para manajer memiliki kesempatan untuk berpartisipasi secara aktif dalam proses penyusunan anggaran yang pada akhirnya akan memberikan dukungan motivasi kepada bawahan untuk meningkatkan kinerjanya.

Rihardjo (2009), menguji pengaruh desentralisasi dan komitmen organisasional terhadap hubungan antara penganggaran partisipatif dan kinerja manajerial. Sampel penelitian dilakukan kepada kepala Satuan Kerja Perangkat Daerah sampai 2 tingkat dibawah kepala SKPD yang menjadi peserta workshop nasional pengelolaan keuangan daerah. Hasil Penelitian membuktikan bahwa interaksi antara penganggaran partisipatif dan struktur organisasi desentralisasi secara signifikan mempengaruhi kinerja manajerial. Gul et al. (1995) dalam penelitiannya membuktikan bahwa interaksi antara partisipasi penyusunan anggaran dengan pelimpahan wewenang yang terdesentralisasi secara positif signifikan mempengaruhi kinerja manajerial. Hal ini menunjukan bahwa semakin tinggi tingkat desentralisasi yang diberikan pada manajer dalam berpartisipasi pada proses penyusunan anggaran akan mengakibatkan kinerja manajerial yang semakin tinggi pula. Coryanata (2004), menguji pelimpahan wewenang dan komitmen organisasi dalam hubungan antara partisipasi penyusunan anggaran dan kinerja manajerial. Hasil penelitiannya membuktikan bahwa hubungan antara partisipasi dalam penyusunan anggaran dan kinerja manajerial positif dan signifikan hanya pada pelimpahan wewenang yang terdesentralisasi serta interaksi komitmen organisasi yang tinggi. Riyadi (2007) menguji pengaruh desentralisasi, motivasi dan partisipasi anggaran terhadap kinerja manajerial. Hasil penelitiannya membuktikan bahwa 1) desentralisasi memiliki pengaruh yang positif terhadap partisipasi anggaran, yang mana dengan semakin tinggi tingkat desentralisasi dalam pengambilan keputusan yang diberikan kepada manajer, maka semakin tinggi pula partisipasi manajer dalam keterlibatan penyusunan anggaran. 2) secara signifikan desentralisasi mempengaruhi kinerja manaje rial dengan tingkat signifikansi sebesar 5\%, koefisien jalur dari pengaruh tersebut sebesar 0,204 dengan nilai probability sebesar 0,035 . Hasil ini menunjukkan bahwa semakin tinggi tingkat desentralisasi yang diberikan pimpinan kepada bawahan atau manajer, maka semakin tinggi pula kinerja manajerial yang diperoleh manajer tersebut. Hal ini berarti bahwa pembagian kekuasaan yang terdesentralisasi mendorong para manajer/bawahan untuk berpartisipasi aktif dalam penyusunan anggaran. Adi (2006) menguji pengaruh partisipasi penyusunan anggaran terhadap kinerja pemimpin dengan desentralisasi dan dukungan organisasi sebagai variabel moderating. Hasil penelitian membuktikan bahwa pengaruh partisipasi anggaran setelah berinteraksi dengan desentralisasi ditunjukkan dengan koefisien negatif $-72,375$ dan tidak signifikan 0,092, hal ini membuktikan bahwa pengaruh partisipasi dalam penyusunan anggaran tetap tidak mendukung walaupun pada pelimpahan wewenang yang terdesentralisasi dalam mempengaruhi kinerja pemimpin dengan baik. Nor (2007), menguji desentralisasi dan gaya kepemimpinan sebagai variabel moderating dalam hubungan antara partisipasi penyusunan anggaran 
dan kinerja manajerial. Hasil penelitian ini tidak memperoleh dukungan yang signifikan terhadap hipotesis yang menyatakan bahwa semakin tinggi tingkat kesesuaian antara partisipasi dalam penyusunan anggaran dengan desentralisasi, maka semakin tinggi kinerja manajerial. Kondisi ini disebabkan oleh adanya faktor seperti struktur organisasi yang masih terpusat (sentralistis), dimana para manajer level bawah tidak didelegasikan untuk membuat kebijakan secara independen karena manajer level atas berasumsi bahwa tanggungjawab akhir atas tugas yang dilakukan oleh para manajemen level bawah juga merupakan tanggungjawabnya.

Berdasarkan bukti-bukti empiris yang dikemukakan diatas, maka rumusan hipotesis yang dikembangkan dalam penelitian ini adalah sebagai berikut:

$\mathrm{H}_{4}$ : Desentralisasi memoderasi pengaruh Partisipasi penyusunan anggaran terhadap kinerja Manajerial secara positif

Hubungan antar variabel tersebut dapat digambarkan sebagai berikut:

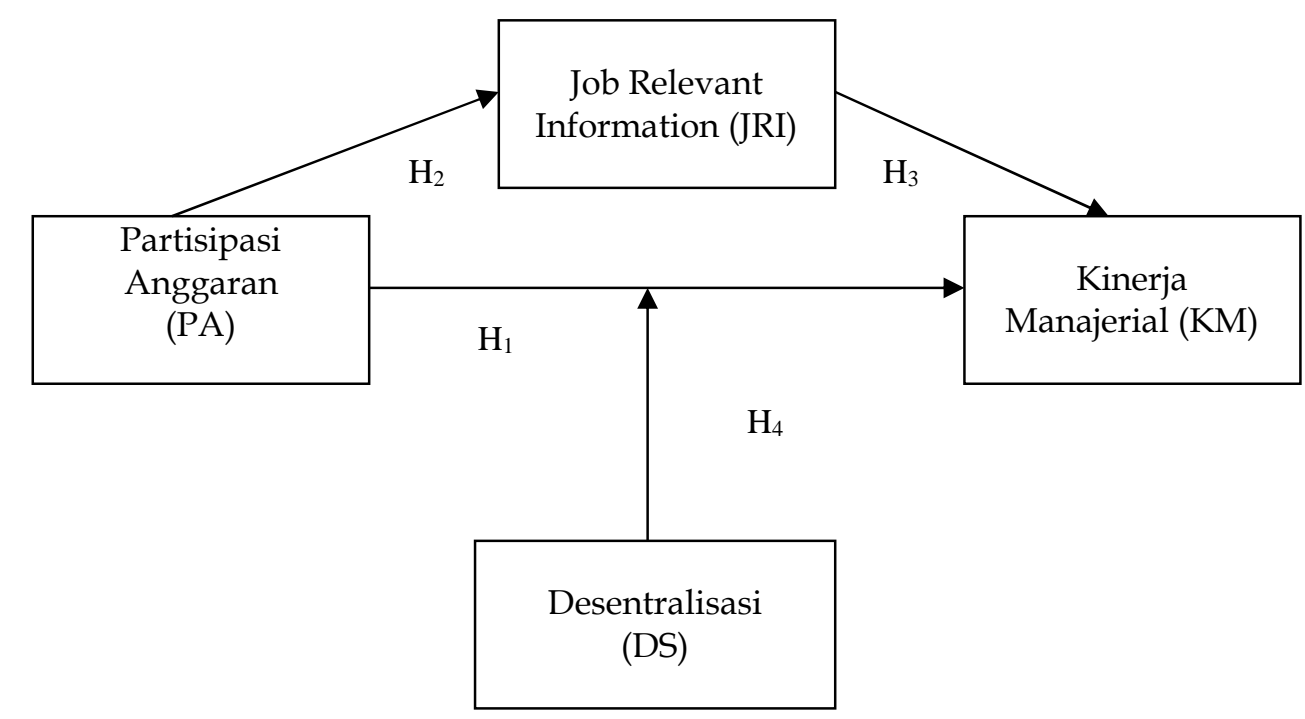

Sumber : Analisis Penulis

\section{Gambar 1 \\ Rerangka Konseptual}

\section{METODE PENELITIAN}

Pendekatan penelitian ini adalah positivistik. Dalam penelitian ini metode yang digunakan adalah metode penelitian survey. Jenis penelitian ini adalah deskriptif verifikatif (causal) yang bertujuan untuk menjelaskan aspek-aspek yang relevan dengan fenomena yang diamati dan untuk mengetahui hubungan kausalitas antar variabel melalui suatu pengujian hipotesis. Lokasi penelitian yaitu pada perusahaan manufaktur yang ada di wilayah Jawa Timur berdasarkan data dari Badan Pusat Statistik tahun 2013.
Populasi dalam penelitian ini adalah seluruh perusahaan dalam berbagai industri di Jawa Timur pada tahun 2013 yang jumlahnya sebanyak 6288 buah, disajikan pada Tabel 1.

\section{Statistik tahun 2013}

Sampel dalam penelitian ini ditetapkan dengan menggunakan rumus dari Slovin (Riduwan dan Kuncoro, 2012) s̀̀bb:"

$$
\begin{aligned}
n & =\frac{N}{N \cdot d^{2+1}}=\frac{6288}{\left(6288 \times 0.1^{2}\right)+1} \\
& =99,8=100(\text { dibulatkan })
\end{aligned}
$$


Tabel 1

Data Populasi Perusahaan Manufaktur berskala sedang dan besar di Jawa Timur Tahun 2013

\begin{tabular}{clr}
\hline \hline No. & \multicolumn{1}{c}{ Jenis Industri } & Jumlah \\
\hline 1 & Industri makanan & 1.630 \\
2 & Industri minuman & 23 \\
3 & Industri pengolahan tembakau & 559 \\
4 & Industri tekstil & 476 \\
5 & Industri pakaian jadi & 538 \\
6 & Industri kulit, barang dari kulit, dan alas kaki & 337 \\
7 & Idustri kayu, barang dari kayu, gabus dan barang anyaman dari & 353 \\
& rotan, bambu, dan sejenisnya & \\
8 & Industri kertas dan barang dari kertas & 152 \\
9 & Industri percetakan dan reproduksi media rekaman & 102 \\
10 & Industri produk dari batubara dan penggilingan minyak bumi & 19 \\
11 & Industri bahan kimia dan barang dari bahan kimia & 202 \\
12 & Industri farmasi, produk obat kimia, dan obat tradisional & 64 \\
13 & Industri karet, barang dari karet dan plastik & 429 \\
14 & Industri barang galian bukan logam & 334 \\
15 & Industri logam dasar & 91 \\
16 & Industri barang logam bukan mesin dan peralatannya & 207 \\
17 & Industri komputer, barang elektronik, dan opteik & 27 \\
18 & Industri peralatan listrik & 66 \\
19 & Industri mesin dan perlengkapan & 69 \\
20 & Industri kendaraan bermotor, trailer, dan semi trailer & 58 \\
21 & Industri alat angkut lainnya & 62 \\
22 & Industri furnitur & 410 \\
23 & Industri pengolahan lainnya & 23 \\
24 & Iasa reparasi dan pemasangan mesin dan peralatan & 21 \\
25 & Industri alat angkutan, selain kendaraan bermotor roda empat atau & 1 \\
& lebih & \\
26 & Industri pengolahan lainnya & \\
27 & Industri daur ulang & Total \\
\hline
\end{tabular}

Sumber: data diolah dari Badan Pusat

Berdasarkan rumus slovin diatas, maka banyaknya sampel yang akan digunakan dalam penelitian ini sebanyak 100 responden. Metode pengambilan sampel nonprobabilitas ini dilakukan dengan metode purposive sampling. Purposive sampling merupakan pemilihan sampel yang sesuai dengan tujuan penelitian. Responden yang diharapkan dalam penelitian ini adalah seluruh manajer yang terlibat dalam proses penyusunan anggaran termasuk didalam- nya adalah manajer level satu sampai level empat dibawah direktur utama.

Penelitian ini, menggunakan data sekunder dan data primer. Data sekunder diperoleh dari Badan Pusat Statistik Jawa Timur tahun 2013 sedangkan data primer merupakan data yang langsung diperoleh dari subjek yaitu berupa persepsi manajer. Instrumen yang digunakan dalam penelitian ini yaitu berupa kuesioner. 


\section{Operasional Variabel}

Partisipasi Anggaran (PA), Partisipasi anggaran berhubungan dengan keterlibatan manajer untuk ikut serta dalam menentukan tujuan yang hendak dicapai oleh perusahaan, diwujudkan dalam bentuk perencanaan aktivitas unit organisasi dalam penyusunan anggaran. Partisipasi penyusunan anggaran diukur dengan menggunakan instrumen Chong dan Chong (2002). Indikator yang digunakan antara lain: Keterlibatan, Ide, Usulan, Kontribusi, Revisi Anggaran.

Job Relevant Information (JRI) sebagai variabel intervening berhubungan dengan kemampuan untuk menerima informasi yang relevan dengan bidang pekerjaan/ tugas yang diberikan atasan, sehingga dapat digunakan untuk pengambilan keputusan yang efektif dan mampu mengevaluasi alternatif-alternatif keputusan penting. JRI diukur menggunakan instrumen Kren (1992). Indikator yang digunakan antara lain: Pemahaman, Kecukupan Informasi, Informasi Strategis, Kejelasan Informasi, Kemampuan mendapat Informasi, Mengetahui lingkungan eksternal perusahaan.

Desentralisasi (DS), sebagai variabel moderating merupakan penyebaran pelimpahan wewenang/kekuasaan secara meluas didalam membuat keputusan oleh tingkatan manajer yang lebih rendah. Desentralisasi diukur menggunakan instrumen Gul et al. (1995). Indikator yang digunakan antara lain: Jalur komunikasi, Proses sistematis, Pelimpahan wewenang dalam pengambilan keputusan, Pengembangan kerja sama tim, Pelatihan dan pengembangan staff, Pengalokasian sumber dana, Staff: Promosi dan mutasi.

Kinerja Manajerial (KM), Kinerja berhubungan dengan pencapaian tujuan anggaran dengan mempertimbangkan sisi motivasi untuk mencapainya. Kinerja diukur dengan menggunakan instrumen Kren (1992). Indikator yang digunakan antara lain: Perencanaan, Investigasi, Pengkoordinasian, Evaluasi, Pengawasan, Pe- milihan Staff, Negosiasi, Perwakilan, Tingkat Kinerja.

\section{Analisis Data \\ Uji Validitas dan Reliabilitas}

Pengujian validitas dan reliabilitas yang dilakukan dalam penelitian ini menggunakan SPSS. Pengujian ini dimaksudkan untuk menambah keyakinan peneliti terhadap penggunaan instrumen yang telah digunakan oleh peneliti terdahulu dan telah dimodifikasi sesuai dengan kebutuhan pada penelitian ini. Pengujian terhadap variabel penelitian ini menggunakan model Analysis path dan Moderating Regression Analysis.

\section{Uji Normalitas Data}

Uji normalitas bertujuan untuk menguji apakah dalam model regresi, variabel terikat dan variabel bebas keduanya mempunyai distribusi data normal ataukah tidak (Ghozali, 2011). Model regresi yang baik adalah memiliki distribusi data normal atau mendekati normal.

\section{Teknik Pengujian Hipotesis}

Hipotesis 1 sampai dengan hipotesis 3 diuji dengan menggunakan model analisis jalur (Analysis path), dengan bentuk persamaannya sebagai berikut:

$\mathrm{KM}=\rho \mathrm{PA}+\rho \mathrm{JRI}+{ }_{\mathrm{e} 2}$

$\mathrm{JRI}=\rho \mathrm{PA}+{ }_{\mathrm{e} 1}$

Sedangkan hipotesis $4 \quad\left(\mathrm{H}_{4}\right)$ diuji menggunakan MRA (Moderating Regression Analysis), dengan bentuk persamaannya sebagai berikut:

$\mathrm{KM}=\lambda \mathrm{PA}+\lambda \mathrm{DS}+\lambda \mathrm{PA}^{*} \mathrm{DS}+{ }_{\mathrm{e} 3}$

Keterangan:

$\mathrm{KM}=$ Kinerja Manajerial

PA = Partisipasi Penyusunan Anggaran

JRI = Job Relevant Information

DS = Desentralisasi

$\mathrm{PA}^{*} \mathrm{DS}=$ Interaksi Penyusunan Anggaran dan Desentralisasi

$\lambda=$ Koefisien MRA

$\rho \quad=$ Koefisien Path

e1 - e3 $=$ Residual yang distandarisasi 
Kriteria Pengujian hipotesis 1-4 adalah sebagai berikut:

a) Hipotesis 1 sampai dengan hipotesis 3 menggunakan koefisien $\rho, \mathrm{H}_{0}$ diterima jika nilai $\mathrm{t}$ hitung $<\mathrm{t}$ tabel atau nilai $\mathrm{p}$ value $>\alpha 0,05$, dan $\mathrm{H}_{\mathrm{a}}$ diterima jika nilai $\mathrm{t}$ hitung $>\mathrm{t}$ tabel atau nilai $\mathrm{p}$ value $<\alpha$ 0,05 .

b) Hipotesis 4 menggunakan koefisien $\lambda, \mathrm{H}_{0}$ diterima jika nilai $\mathrm{t}$ hitung $<\mathrm{t}$ tabel atau nilai $\mathrm{p}$ value $>\alpha 0,05$ dan $\mathrm{H}_{\mathrm{a}}$ diterima jika $\lambda>0$ dan nilai $\mathrm{t}$ hitung $>\mathrm{t}$ tabel atau nilai $\mathrm{p}$ value $<\alpha 0,05$.

\section{ANALISIS DAN PEMBAHASAN \\ Proses Pengambilan Data di Lapangan}

Penyebaran kuesioner ini dilakukan dengan 2 cara yaitu mengantar langsung ke perusahaan dan menggunakan jasa pengiriman pos (mail survey). Kuesioner yang dikirim melalui pos sejumlah 360 set dan

\section{Deskripsi Karakteristik Responden}

yang diantarkan langsung sejumlah 40 set (Total 400set), Jumlah kuesioner yang kembali 107set dan dari jumlah tersebut ada 16 responden yang mengisi data secara tidak lengkap serta respondennya tidak sesuai dengan kriteria yang ditetapkan peneliti, sehingga kuesioner yang dapat digunakan untuk dianalisis adalah sebanyak 91 responden.

Berdasarkan Tabel 2 terlihat bahwa jumlah dan jabatan responden yang terlibat dalam proses penyusunan anggaran pada perusahaan manufaktur di Jawa Timur yaitu terdiri dari $54,9 \%$ middle manager, lower manager 38,5\%, Lainnya 5,5\% dan $1,1 \%$ adalah top manager. Hal ini mengindikasikan bahwa perusahaan sudah melibatkan manajer tingkat bawah di dalam penyusunan anggaran namun keterlibatannya belum secara merata.

Tabel 2

Karakteristik Responden Berdasarkan Jabatan

\begin{tabular}{clcc}
\hline No. & \multicolumn{1}{c}{ Jabatan } & Frekuensi & Prosentasi (\%) \\
\hline 1 & Top Management & 1 & 1,1 \\
2 & Middle Management & 50 & 54,9 \\
3 & Lower Management & 35 & 38,5 \\
4 & Lainnya (sub bagaian) & 5 & 5,5 \\
& Total & 91 & $100 \%$
\end{tabular}

Sumber : Data Olahan Penulis dari SPSS

Tabel 3

Karakteristik Responden Berdasarkan Pendidikan

\begin{tabular}{cccc}
\hline No & Pendidikan & Frekuensi & Prosentase (\%) \\
\hline 1 & SMU & 6 & 6,6 \\
2 & D3 & 28 & 30,8 \\
3 & S-1 & 47 & 51,6 \\
4 & S-2 & 10 & 11,0 \\
5 & S-3 & 0 & 0 \\
\hline & Total & 91 & $100 \%$ \\
\hline
\end{tabular}

Sumber : Data Olahan Penulis dari SPSS 
Pada Tabel 3 diatas terlihat bahwa karakteristik responden berdasarkan pendidikan sebagian besar adalah tenaga kerja berpendidikan tinggi, dimana sebesar 51,6\% adalah sarjana S-1, 30,8\% adalah Diploma, $11,0 \%$ adalah S-2. Hal ini menunjukkan bahwa tingkat pendidikan responden sangat penting untuk menduduki jabatan sebagai top manager, middle manager, lower manager, Lainnya (sub bagian) didalam organisasi perusahaan.

\section{Uji Validitas dan Realibilitas}

Hasil uji validitas dan realibilitas instrumen variabel Partisipasi, JRI, Desentralisasi dan Kinerja Manajerial memiliki hasil uji signifikan korelasi (r) lebih besar dari $\mathrm{r}$ tabel $=0,2605$, dan memiliki koefisien cronbach alpha 0.797 lebih dari 0,60 sehingga semua variabel pada tiap item pertanyaan dikatakan valid dan reliable untuk dapat digunakan dalam pengolahan data selanjutnya.

\section{Uji Normalitas}

Hasil pengujian uji normalitas terlihat pada kolom Kolmogorov-smirnov dapat dilihat pada tabel 4 .

Hasil pengujian uji normalitas pada tabel 4 terlihat bahwa nilai signifikan Partisipasi $=0,068$, JRI $=0,062$, Desentralisasi $=0,083$ dan Kinerja $=0,085$. Karena signifikansi untuk seluruh variabel lebih besar dari 0,05 maka dapat disimpulkan bahwa data berdistribusi normal.

\section{Analisis Pengaruh Partisipasi terhadap Kinerja Manajerial}

Hasil analisis regresi antara Partisipasi anggaran terhadap Kinerja Manajerial disajikan pada tabel 5 .

Tabel 4

Hasil Uji Normalitas

\begin{tabular}{lccc}
\hline \hline \multicolumn{3}{c}{ Kolmogorov-Smirnov $^{\mathbf{a}}$} \\
\hline Statistik & $\mathrm{df}$ & Sig \\
\hline Partisipasi & 0,112 & 91 & 0,068 \\
JRI & 0,152 & 91 & 0,062 \\
Desentralisai & 0,119 & 91 & 0,083 \\
Kinerja & 0,097 & 91 & 0,085 \\
\hline
\end{tabular}

Sumber: (data) diolah Penulis dari SPSS

Tabel 5

Pengujian Model Hipotesis 1

\begin{tabular}{llcc}
\hline \hline $\begin{array}{l}\text { Variabel } \\
\text { Independen }\end{array}$ & $\begin{array}{l}\text { Koefisien } \\
\text { Path }\end{array}$ & Nilai t & Nilai $\mathrm{p}$ \\
\hline Partisipasi(PA) & 0,376 & 3,782 & 0,000 \\
Variabel dependen & $:$ Kinerja & Manajerial (KM) \\
R square & $: 0,444$ & & \\
Koefisien korelasi (rKMPA) & $: 0,595$ & & \\
\hline Sumber: Data Olahan Penulis (SPSS) & & &
\end{tabular}

Hasil pengujian empiris pada hipotesis pertama membuktikan bahwa partisipasi penyusunan anggaran berpengaruh positif signifikan terhadap kinerja manajerial. Hal ini terlihat dari hasil analisis diperoleh koefisien path sebesar 0,376, secara statistik variabel ini berpengaruh signifikan dengan nilai t-hitung sebesar 3,782 serta didukung 
dengan $p$ value sebesar $0,000<0,05$ artinya bahwa Ho ditolak dan $\mathrm{H}_{1}$ diterima, bukti empiris ini menyatakan bahwa tingginya partisipasi dari manajer tingkat bawah dalam penyusunan anggaran akan meningkatkan kinerja manajerial. Besarnya $\mathrm{R}$ square adalah 0,444 yang mengindikasikan bahwa kontribusi variabel partisipasi dan JRI terhadap kinerja manajerial sebesar $44,4 \%$ dan sisanya sebesar $55,6 \%$ dipengaruhi oleh faktor lain diluar model penelitian ini.

Hasil temuan ini konsisten dengan penelitian Yusfaningrum dan Ghozali (2005) yang memasukkan variabel komitmen tujuan anggaran dan JRI sebagai variabel intervening untuk menguji hubungan partisipasi anggaran dan kinerja manajerial, hasil penelitiannya membuktikan bahwa partisipasi anggaran berpengaruh positif dan signifikan terhadap kinerja manajerial. Penelitian ini sejalan dengan penelitian Kren (1992), Gul et al (1995), Rosidi (2000), Chong dan Chong (2002), Coryanata (2004), Nor (2007), Rihardjo (2009) serta Indarto dan Ayu (2011) yang membuktikan bahwa partisipasi anggaran secara positif signifikan memiliki hubungan dengan kinerja manajerial secara langsung.

Melalui penyusunan anggaran secara partisipatif pada perusahaan manufaktur, maka kinerja para manajer tingkat bawah akan semakin tinggi dengan dasar pemikiran bahwa ketika rancangan anggaran secara partisipatif dapat terlaksana, maka karyawan akan menginternalisasikan tujuan atau standar yang sudah ditetapkan dan secara individu memiliki rasa tanggungjawab untuk mencapai tujuan tersebut karena mereka merasa sudah ikut serta dan terlibat dalam penyusunan anggaran. Internalisasi tujuan organisasi memiliki peranan penting didalam meningkatkan efektifitas organisasi dengan mengurangi terjadinya konflik kepentingan antara tujuan pribadi dan tujuan organisasi perusahaan. Partisipasi memunculkan rasa percaya diri yang tinggi dari seorang manajer tingkat bawah sebagai bentuk motivasi dalam diri untuk memberikan ide/gagasan anggaran, usulan anggaran, kontribusi anggaran, merevisi anggaran, sehingga keterlibatannya dalam penyusunan anggaran akan meningkatkan rasa tanggungjawab dalam mewujudkan sasaran anggaran dan meningkatkan kinerja manajerial yang meliputi perencanaan, investigasi, pengkoordinasian, evaluasi, pengawasan, pemilihan staff, negosiasi, perwakilan dan kinerjanya secara keseluruhan. Sehingga dapat disimpulkan bahwa program anggaran pada perusahaan manufaktur di Jawa Timur akan jauh lebih berhasil jika bawahan dilibatkan atau diperkenankan bertanggung jawab mengendalikan biaya dan menyusun anggaran untuk masing-masing area pertanggungjawaban.

Hasil temuan penelitian ini tidak mendukung penelitian yang dilakukan Adi (2006) yang telah membuktikan bahwa partisipasi tidak mempunyai pengaruh langsung terhadap kinerja manajer, hal ini disebabkan karena adanya pengaruh dari variabel-variabel lain.

\section{Analisis Pengaruh Partisipasi Anggaran terhadap Job Relevant Information}

Hasil analisis regresi antara partisipasi penyusunan anggaran terhadap Job relevant information disajikan pada tabel 6 .

Hasil pengujian empiris pada hipotesis kedua yang membuktikan bahwa partisipasi penyusunan anggaran berpengaruh positif signifikan terhadap job relevant information sebagai variabel intervening. Hal ini terlihat dari hasil analisis diperoleh koefisien path sebesar 0,578, secara statistik variabel ini berpengaruh signifikan dengan nilai t-hitung sebesar 6,679 dan didukung dengan $p$ value sebesar $0,000<0,05$ artinya bahwa hipotesis Ho ditolak dan $\mathrm{H}_{1}$ diterima.

Hal ini menunjukkan bahwa tingginya partisipasi dalam penganggaran akan meningkatkan penggunaan job relevant information. 
Tabel 6

Pengujian Model Hipotesis 2

\begin{tabular}{lccc}
\hline \hline Variabel Independen & Koefisien Path & Nilai t & Nilai $\mathrm{p}$ \\
\hline Partisipasi (PA) & 0,578 & 6,679 & 0,000 \\
Variabel dependen & $:$ JRI & & \\
R square & $: 0,334$ & & \\
Koefisien korelasi (rJRIPA) & $: 0,578$ & & \\
\hline Sumber : Data Olahan Penulis (SPSS) & & &
\end{tabular}

Besarnya R square adalah 0,334 yang mengindikasikan bahwa kontribusi variabel partisipasi terhadap JRI sebesar 33,4\% dan sisanya sebesar 66,6\% dipengaruhi oleh faktor lain diluar model penelitian ini.

Penelitian ini konsisten dengan penelitian yang dilakukan Indarto dan Ayu (2011) yang menguji pengaruh partisipasi dalam penyusunan anggaran terhadap kinerja manajerial perusahaan melalui kecukupan anggaran, komitmen organisasi, komitmen tujuan anggaran, dan Job Relevant Information. Hasil pengujian menunjukkan bahwa partisipasi anggaran secara signifikan berhubungan dengan kecukupan anggaran, komitmen organisasi, komitmen tujuan anggaran dan Job Relevant Information sehingga dapat dikatakan bahwa penelitian ini mendukung hipotesis alternatif (Ha) diterima. Yusfaningrum dan Ghozali (2005) yang menganalisis pengaruh partisipasi anggaran terhadap kinerja manajerial melalui komitmen tujuan anggaran dan $\mathrm{Job}$ Relevant Information sebagai variabel intervening, penelitiannya berhasil membuktikan bahwa partisipasi berpengaruh positif dan signifikan terhadap job relevant information. Dalam proses partisipasi, bawahan diberi kesempatan untuk memberikan masukan berupa informasi yang dimilikinya kepada atasan sehingga atasan akan memperoleh pemahaman yang lebih baik tentang pengetahuan yang relevan dengan tugas (task relevant knowledge). Penelitian ini juga didukung oleh penelitian Kren (1992) yang menunjukkan bahwa job relevant information berfungsi sebagai variabel intervening antara partisipasi anggaran dan kinerja manajerial. Dari hasil penelitian Kren (1992) memberikan bukti bahwa partisipasi berhubungan positif dengan JRI, dengan diperolehnya JRI maka kinerja manajerial akan meningkat. Rosidi (2000), Marsudi dan Ghozali (2001), Chong dan Chong (2002) berhasil membuktikan bahwa partisipasi berpengaruh positif dan signifikan terhadap job relevant information. Partisipasi dapat dikatakan sebagai suatu proses pengambilan keputusan secara bersama oleh dua pihak atau lebih. Melalui proses partisipasi, bawahan mendapat kesempatan untuk memberikan masukan berupa informasi kepada atasannya sehingga atasan memperoleh pemahaman yang lebih baik tentang pengetahuan yang relevan dengan tugas.

Berdasarkan hasil penelitian ini maka dapat dikatakan bahwa semakin tingginya keterlibatan manajer tingkat bawah pada perusahaan manufaktur didalam penyusunan anggaran dengan memberikan ide anggaran, usulan anggaran, kontribusi anggaran, merevisi anggaran pada masing-masing area pertanggungjawaban menyebabkan penggunaan job relevant information yang tinggi. Hal ini menunjukkan bahwa penggunaan partisipasi dalam penganggaran dengan melibatkan manajer tingkat bawah akan meningkatkan penggunaan job relevant information karena melalui penyusunan anggaran secara partisipatif memungkinkan bawahan untuk dapat saling bertukar informasi dengan atasan, sehingga dapat mendukung terciptanya pemahaman yang lebih baik mengenai proses penyusunan anggaran yang relevan dengan tugas. Selain itu dengan adanya partisipasi anggaran, me- 
mungkinkan bawahan untuk mengemukakan kritiknya serta mencari informasi bagi penyelesaian tugas.

\section{Analisis Pengaruh JRI terhadap Kinerja Manajerial}

Hasil analisis regresi Job relevant information terhadap Kinerja Manajerial disajikan pada tabel 7. Hasil pengujian empiris pada hipotesis ketiga membuktikan bahwa job relevant information berpengaruh positif siginifikan terhadap kinerja manajerial.

Hal ini terlihat dari hasil analisis diperoleh koefisien path sebesar 0,248, secara statistik variabel ini berpengaruh signifikan dengan nilai t-hitung sebesar 2,251 didukung dengan $p$ value sebesar 0,027 $<0,05$, artinya bahwa hipotesis Ho ditolak dan $\mathrm{H}_{1}$ diterima.

Tabel 7

Pengujian Model Hipotesis 3

\begin{tabular}{llcc}
\hline \hline $\begin{array}{l}\text { Variabel } \\
\text { Independen }\end{array}$ & $\begin{array}{l}\text { Koefisien } \\
\text { Path }\end{array}$ & Nilai t & Nilai $\mathrm{p}$ \\
\hline JRI & 0,248 & 2,251 & 0,027 \\
Variabel dependen & $:$ Kinerja Manajerial $(\mathrm{KM})$ \\
R square & $: 0,444$ & & \\
Koefisien korelasi $(r K M J R I)$ & $: 0,564$ & & \\
\hline Sumber : Data Olahan Penulis (SPSS & &
\end{tabular}

Hal ini menunjukkan bahwa semakin tinggi penggunaan Job Relevant Information akan meningkatkan kinerja manajerial. Besarnya R square adalah 0,444 yang mengindikasikan bahwa kontribusi variabel partisipasi dan JRI terhadap kinerja manajerial sebesar $44,4 \%$ dan sisanya sebesar $55,6 \%$ dipengaruhi oleh faktor lain diluar model penelitian ini.

Hasil temuan ini konsisten dengan penelitian yang dilakukan oleh Indarto dan Ayu (2011) yang menguji pengaruh partisipasi dalam penyusunan anggaran terhadap kinerja manajerial perusahaan melalui kecukupan anggaran, komitmen organisasi, komitmen tujuan anggaran, dan Job Relevant Information yang membuktikan bahwa Job Relevant Information secara signifikan berhubungan dengan kinerja manajerial sehingga dapat dikatakan penelitian ini mendukung hipotesis alternatif $(\mathrm{Ha})$ diterima. Hal ini sesuai dengan keadaan yang terjadi pada perusahaan besar di Jawa Tengah yang menerapkan manajer tingkat menengah (manajer fungsional) turut berperan aktif dalam penyusunan anggaran untuk meningkatkan kinerja manajerialnya dengan memberikan kecukupan anggaran, komitmen organisasi, komitmen tujuan anggaran, dan Job Relevant Information bagi para manajernya. Penelitian ini juga didukung oleh Kren (1992), Rosidi (2000), Marsudi dan Ghozali (2001), Chong dan Chong (2002) yang menemukan bukti bahwa Job Relevant Information dan kinerja manajerial berhubungan secara positif dan signifikan. Job relevant information berhubungan dengan penilaian seberapa luas kemampuan manajer untuk menerima informasi yang dapat digunakan dalam pengambilan keputusan yang efektif serta mengevaluasi alternatif-alternatif keputusan penting.

Suatu keputusan dikatakan dapat meningkatkan kinerja manajer secara efektif, apabila dalam proses pengambilan keputusan memiliki ketersediaan informasi yang cukup dan akurat. Bawahan biasanya memiliki informasi yang lebih akurat mengenai faktor-faktor yang mempengaruhi kinerja, daripada atasan mereka (Kren, 1992). Tersedianya informasi yang ber- 
hubungan dengan tugas akan meningkatkan perencanaan untuk mencapai tujuan yang ditetapkan, yang pada akhirnya akan meningkatkan kinerja. Dengan penggunaan Job Relevant Information oleh manajer tingkat bawah pada perusahaan manufaktur maka para manajer akan memiliki pemahaman yang lebih baik dalam memilih alternatif tindakan yang diperlukan untuk pengambilan keputusan yang sesuai dengan tujuan perusahaan. Tindakan yang tepat akan meningkatkan pencapaian hasil yang lebih baik sehingga akan meningkatkan kinerja manajerial. Hal ini menunjukkan bahwa dengan adanya ketersediaan informasi yang cukup dan relevan dengan tugas bagi para manajer tingkat bawah didalam menyelesaikan pekerjaannya, maka dapat dikatakan bahwa pekerjaannya dapat berjalan dengan baik dan bahkan dapat meningkatkan pencapaian kinerja manajerial yang menyangkut perencanaan, Investigasi, pengkoordinasian, evaluasi, pengawasan, pemilihan staf, negosiasi, perwakilan, kinerja secara keseluruhan.
Akan tetapi hasil penelitian ini tidak mendukung penelitian yang dilakukan oleh Yusfaningrum dan Ghozali (2005) yang menemukan bahwa hubungan job relevant information dengan kinerja manajerial memiliki hubungan positif tidak signifikan. Hal ini disebabkan karena adanya penerapan dimensi budaya organisasi power distance yang lebar dimana para atasan mempunyai otoritas yang mutlak, akibatnya penetapan tujuan anggaran yang cenderung bersifat subyektif serta mengarah kepada kepentingan principal sehingga penggunaan JRI yang dilakukan manajer tidak signifikan dengan peningkatan kinerja manajerial.

Analisis Desentralisasi memoderasi Pengaruh Partisipasi terhadap Kinerja Manajerial

Hasil perhitungan analisis MRA variabel Desentralisasi sebagai pemoderasi hubungan antara partisipasi terhadap Kinerja Manajerial disajikan pada tabel 8 .

Tabel 8

\section{Pengujian Model Hipotesis 4}

\begin{tabular}{llll}
\hline \hline Variabel Independen & Koefisien MRA & Nilai t & Nilai $\mathrm{p}$ \\
\hline PA*DS & $-1,562$ & $-1,236$ & 0,220 \\
Variabel dependen & $:$ Kinerja Manajerial $(\mathrm{KM})$ & \\
R square & $: 0,414$ & \\
\hline \multicolumn{2}{l}{ Sumber : Data Olahan Penulis dari (SPSS }
\end{tabular}

Berdasarkan hasil analisis MRA (moderated regression analysis) di atas, diperoleh koefisien MRA sebesar (-1.562), secara statistik hasil ini berpengaruh secara negatif tidak signifikan dengan nilai $t$ hitung sebesar -1,236 dan p-value sebesar 0,220 > 0,005, maka dapat dikatakan bahwa $\mathrm{H}_{0}$ diterima dan $\mathrm{H}_{1}$ ditolak. Dengan demikian, dapat disimpulkan bahwa desentralisasi tidak memoderasi hubungan partisipasi terhadap kinerja manajerial. Besarnya $\mathrm{R}$ square adalah 0,414 yang mengindikasikan bahwa kontribusi variabel desentralisasi dalam memoderasi hubungan partisipasi terhadap kinerja sebesar $41,4 \%$ dan sisanya sebesar $58,6 \%$ dipengaruhi oleh faktor lain diluar model penelitian ini.

Hasil ini dapat diinterpretasikan bahwa desentralisasi memperlemah pengaruh partisipasi penyusunan anggaran terhadap kinerja manajerial, artinya semakin tinggi tingkat desentralisasi, semakin lemah hubungan partisipasi anggaran terhadap kinerja manajerial.

Hasil penelitian pengujian hipotesis 4 ini bertolak belakang dengan penelitian yang dilakukan oleh Rihardjo (2009) yang menguji pengaruh desentralisasi dan 
komitmen organisasional terhadap hubungan antara penganggaran partisipatif dan kinerja manajerial menemukan bahwa interaksi antara penganggaran partisipatif dan struktur desentralisasi organisasi secara signifikan mempengaruhi kinerja manajerial. Gul et al. (1995) yang menguji partisipasi terhadap kinerja manajerial dengan desentralisasi sebagai variabel moderating. Hasilnya menunjukkan bahwa partisipasi anggaran berhubungan positif signifikan dengan kinerja pada tingkat desentralisasi yang tinggi. Hasil penelitian ini juga tidak sejalan dengan penelitian yang dilakukan oleh Coryanata (2004) dan Riyadi (2007) yang membuktikan bahwa hubungan antara partisipasi dalam penyusunan anggaran dan kinerja manajerial positif dan signifikan hanya pada pelimpahan wewenang yang terdesentralisasi.

Pelimpahan wewenang dalam organisasi berkaitan erat dengan struktur organisasi. Pelimpahan wewenang yang terdesentralisasi diperlukan karena dalam struktur yang terdesentralisasi para manajer/bawahan diberikan wewenang dan tanggungjawab yang lebih besar dalam pengambilan keputusan. Berdasarkan hasil pengujian tersebut, menunjukkan bahwa para manajer dalam organisasi perusahaan manufaktur dengan tingkat desentralisasi yang tinggi, merasa dirinya kurang bertanggung jawab dan sedikit terlibat dalam perencanaan anggaran karena merasa mengalami tekanan dari atasan (pimpinan) sehingga para manajer tingkat bawah memandang anggaran sebagai sesuatu hal yang kurang berguna dan membatasi kekuasaan mereka, sehingga dapat dikatakan bahwa dengan adanya penerapan desentralisasi dalam hal komunikasi, proses sistematis, pengambilan keputusan, kerja sama tim, pelatihan dan pengembangan staf, alokasi sumber dana dan staff akan memperlemah hubungan partisipasi penyusunan anggaran terhadap kinerja manajerial. Artinya semakin tinggi tingkat desentralisasi, semakin lemah hubungan partisipasi anggaran terhadap kinerja mana- jerial. Ada 3 hal yang menyebabkan desentralisasi memperlemah pengaruh partisipasi penyusunan anggaran terhadap kinerja manajerial: Pertama, adanya kecenderungan gaya kepemimpinan dalam proses pengambilan keputusan masih berpusat pada pemilik perusahaan (sentralistik) serta adanya tekanan dari pimpinan perusahaan. Adanya tekanan dari pimpinan perusahaan sehingga masih menimbulkan keengganan bagi para manajer di level bawahnya untuk menerapkan desentralisasi. Kedua, masih belum sempurnanya peraturan internal perusahaan yang mengatur proses desentralisasi dalam pengambilan keputusan, khususnya peraturan internal perusahaan. Ketiga, kondisi perusahan manufaktur di daerah Jawa Timur masih didominasi oleh perusahaan Non-go public yang pada dasarnya penerapan kepemimpinan manajerial masih diberlakukan terhadap owner perusahaan sehingga hak desentralisasi dalam hal kepercayaan dan tanggungjawab yang diberikan kepada manajer tingkat bawah tidak diterapkan secara maksimal. Hal ini menandakan bahwa penerapan desentralisasi bagi manajer tingkat bawah pada perusahaan manufaktur di Jawa Timur masih sulit untuk dilakukan.

Akan tetapi hasil penelitian ini sejalan dengan penelitian yang dilakukan oleh Nor (2007) yang menguji Desentralisasi dan gaya kepemimpinan sebagai variabel moderating dalam hubungan antara partisipasi penyusunan anggaran dan kinerja, membuktikan bahwa kesesuain antara partisipasi anggaran dengan variabel kontijensi (desentralisasi) terhadap kinerja manajerial bukanlah merupakan kesesuain terbaik. Kondisi ini disebabkan oleh adanya faktor seperti struktur organisasi yang masih terpusat (sentralistis), dimana para manajer level bawah tidak didelegasikan untuk membuat kebijakan secara independen karena manajer level atas berasumsi bahwa tanggungjawab akhir atas tugas yang dilakukan oleh para manajemen level bawah juga merupakan tanggungjawabnya. Selanjutnya penelitian Adi (2006), yang meng- 
uji partisipasi penyusunan anggaran terhadap kinerja pemimpin dengan menggunakan desentralisasi dan dukungan organisasi sebagai variabel moderating.

Hasilnya membuktikan bahwa dengan adanya interaksi desentralisasi memiliki koefisien negatif $-72,375$ dan signifikansi 0,092 terhadap hubungan partisipasi dan kinerja, hal ini menggambarkan bahwa pengaruh partisipasi dalam penyusunan anggaran tetap tidak mendukung walaupun pada pelimpahan wewenang yang terdesentralisasi dalam mempengaruhi kinerja pemimpin dengan baik.

\section{Model Hasil Penelitian}

Model hasil penelitian dapat dilihat pada gambar 2

\section{Hubungan Pengaruh Langsung dan Tidak Langsung}

Kombinasi hasil koefisien jalur yang diamati, pengaruh langsung, pengaruh tidak langsung dan pengaruh total dapat dilihat pada tabel 9. Pengaruh partisipasi anggaran terhadap kinerja secara langsung sebesar 0,376, sementara pengaruh tidak langsung partisipasi anggaran terhadap kinerja melalui Job Relevant Information sebagai variabel intervening diperoleh dengan cara JRI $=\left(\mathrm{r}_{12} \mathrm{X} \beta \mathrm{KM} \mathrm{JRI}\right)$ atau sebesar 0,143 $=(0,578 \times 0,248)$.

Maka dapat dikatakan bahwa pengaruh partisipasi anggaran terhadap kinerja manajerial melalui JRI sebagai variabel intervening akan dapat memberikan efek mediasi, walaupun tidak terlalu bermakna karena memiliki nilai pengaruh tidak langsung lebih kecil daripada pengaruh langsung $(0,143<0,376)$.

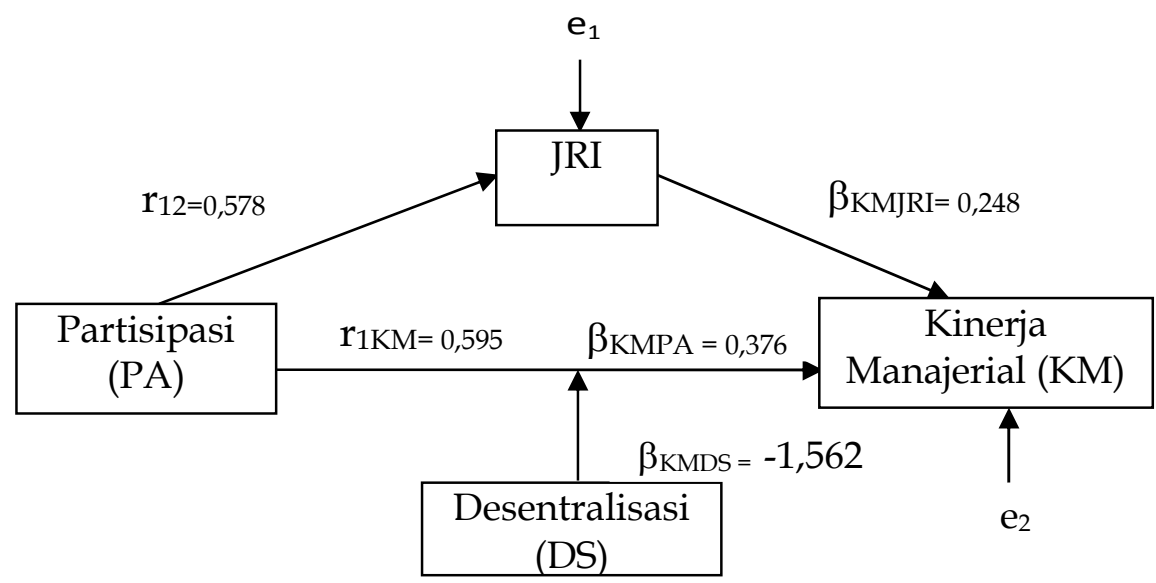

Gambar 2

Hasil Analisis Jalur

Tabel 9

Pengaruh Langsung dan Tidak Langsung

\begin{tabular}{lllll}
\hline \hline $\begin{array}{l}\text { Hubungan } \\
\text { Variabel }\end{array}$ & $\begin{array}{l}\text { Koefisien } \\
\text { Jalur }\end{array}$ & $\begin{array}{l}\text { Pengaruh } \\
\text { langsung }\end{array}$ & $\begin{array}{l}\text { Pengaruh } \\
\text { Tidak Langsung } \\
\text { Melalui JRI }\end{array}$ & $\begin{array}{l}\text { Total } \\
\text { Pengaruh }\end{array}$ \\
\hline $\begin{array}{l}\text { Partisipasi dengan JRI } \\
\text { Partisipasi dengan } \\
\text { Kinerja (melalui JRI) }\end{array}$ & $\mathrm{r}_{12}$ & 0,578 & - & 0,578 \\
\hline
\end{tabular}


Pengaruh total partisipasi anggaran terhadap kinerja manajerial melalui JRI adalah Total $=\left(\mathrm{r}_{1} \mathrm{KM}+\mathrm{JRI}\right)$ atau sebesar $0,519=$ $(0,376+0,143)$, hal ini menunjukkan bahwa dengan keluarnya variabel JRI sebagai variabel intervening maka pengaruh partisipasi terhadap kinerja manajerial semakin lemah yaitu dari 0,519 menjadi 0,376. Sehingga dapat dikatakan bahwa tingginya kinerja manajerial tidak hanya karena partisipasi manajer dalam penyusunan anggaran, tetapi juga karena adanya pengaruh variabel lain yaitu job relevant information.

\section{SIMPULAN, KETERBATASAN, DAN SARAN \\ Simpulan}

Simpulan dari hasil pengujian hipotesis adalah sebagai berikut: Pertama,Secara empiris terbukti bahwa partisipasi penyusunan anggaran berpengaruh secara positif terhadap kinerja manajerial. Ini menunjukkan bahwa semakin tinggi tingkat partisipasi dalam penyusunan anggaran akan meningkatkan kinerja manajerial yang tinggi atau dapat ditarik simpulan bahwa dengan adanya penyusunan anggaran secara partisipatif, maka kinerja para manajer akan semakin tinggi. Kedua, Secara empiris terbukti bahwa partisipasi penyusunan anggaran berpengaruh secara positif terhadap job relevant information sebagai variabel intervening. Hal ini menunjukkan bahwa tingginya partisipasi dalam penganggaran akan meningkatkan penggunaan job relevant information. Melalui penyusunan anggaran secara partisipatif memungkinkan bawahan untuk dapat saling bertukar informasi dengan atasan, sehingga dapat mendukung terciptanya pemahaman yang lebih baik mengenai proses penyusunan anggaran. Ketiga, Secara empiris terbukti bahwa Job relevant information berpengaruh secara positif terhadap kinerja manajerial. Hal ini menunjukkan bahwa semakin tinggi penggunaan Job Relevant Information akan meningkatkan kinerja manajerial. Suatu keputusan dikatakan dapat meningkatkan kinerja manajer secara efektif, apabila dalam proses pengambilan keputusan memiliki ketersediaan informasi yang cukup. Keempat, Secara empiris terbukti bahwa desentralisasi tidak memoderasi hubungan partisipasi penyusunan anggaran terhadap kinerja manajerial dengan koefisien Moderating Regression Analysis bernilai negatif. Artinya bahwa dengan adanya desentralisasi sebagai variabel moderating justru akan memperlemah pengaruh partisipasi penyusunan anggaran terhadap kinerja Manajerial. Hal ini mengindikasikan bahwa para manajer dalam organisasi dengan tingkat desentralisasi yang tinggi, merasa dirinya kurang bertanggung jawab dan sedikit terlibat dalam perencanaan anggaran karena merasa mengalami tekanan dari atasan (pimpinan) sehingga para manajer tingkat bawah memiliki pandangan tentang anggaran sebagai sesuatu hal yang kurang berguna dan bahkan merasa sangat membatasi keluasaannya.

\section{Keterbatasan}

Keterbatasan penelitian ini adalah sebagai berikut: Pertama, Penelitian ini hanya menggunakan hubungan variabel kontijensi berupa JRI sebagai variabel intervening dan desentralisasi sebagai variabel moderating terhadap hubungan partisipasi dengan kinerja manajerial dan tidak mempertimbangkan beberapa variabel kontijensi lainnya yang mungkin mempengaruhi hubungan partisipasi dengan kinerja manajerial yang berkenaan (relevan) dengan situasi dalam penyusunan anggaran pada organisasi perusahaan manufaktur. Kedua, Partisipasi manajer dalam organisasi perusahaan terhadap penyusunan anggaran sudah dilakukan namun masih belum sepenuhnya, hal ini dikarenakan pengambilan keputusan yang bersifat sentralistik dalam penyusunan anggaran yang masih didominasi oleh pemilik perusahaan. Ketiga, Responden terbatas pada manajer dalam perusahaan manufaktur, yang mana kemungkinan penelitian ini akan menunjukkan hasil yang berbeda jika responden yang digunakan pada para manajer unit bisnis 
lainnya, misalkan perusahaan jasa atau perusahaan dagang. Keempat, Pertanyaan kueisoner yang digunakan untuk semua komponen pekerjaan manajer yang berkaitan dengan anggaran masih bersifat umum dan hanya berdasarkan sebuah persepsi, alangkah baiknya penggunaan kuesioner dapat dimodifikasi dan disesuaikan dengan fakta pada masing-masing komponen fungsi dan tugas manajer secara nyata di industri manufaktur. Kelima, Penggunaan jumlah sampel belum representative dengan penetapan jumlah sampling, hal ini dikarenakan adanya beberapa responden yang telah melakukan pengisian kuesioner secara tidak lengkap.

\section{Saran}

Adapun saran untuk peneliti berikutnya: Pertama, Dapat memperluas beberapa hubungan variabel kontijensi lainnya yang (relevan) berkenaan dengan situasi dalam penyusunan anggaran terhadap kinerja organisasi bisnis. Misalnya dengan menambah variabel motivasi, komitmen organisasi, asimetri informasi dan lain-lain. Kedua, Responden terbatas pada manajer dalam perusahaan manufaktur, yang mana kemungkinan penelitian ini akan menunjukkan hasil yang berbeda jika responden yang digunakan pada para manajer unit bisnis lainnya, misalkan perusahaan jasa atau perusahaan dagang. Ketiga, Pertanyaan kuesioner yang digunakan untuk semua komponen pekerjaan manajer yang berkaitan dengan anggaran masih bersifat umum dan hanya berdasarkan persepsi. Pertanyaan kuesioner sebaiknya dimodifikasi dan disesuaikan dengan masingmasing komponen fungsi manajer secara nyata di industri manufaktur. Keempat, Penggunaan jumlah sampel yang belum representative dengan penetapan jumlah sampling, diharapkan untuk penelitian lanjutan jika mengalami kondisi yang sama maka perlu dilakukan pengiriman kuesioner tahap dua untuk dapat melengkapi pengisian kuesioner.

\section{DAFTAR PUSTAKA}

Adi, B. 2006. Pengaruh Partisipasi Penyusunan Anggaran Terhadap Kinerja Pemimpin Dengan Desentralisasi dan Dukungan Organisasi sebagai Variabel Moderating. Thesis. Program Pasca Sarjana Universitas Brawijaya. Malang.

Apriwandi. 2012. Pengaruh Locus of Control, Budaya Paternalistik, Kapasitas Individu, terhadap Keefektifan Penganggaran Partisipatif dan Budgetary Slack dalam Peningkatan Kinerja Manajerial. Jurnal Kajian Manajemen Bisnis 1(2): 109-133.

Badan Pusat Statistik Jatim. 2013. Direktori Perusahaan Industri Besar dan Sedang Jawa Timur Tahun 2013. CV. Bina Media Mandiri.Surabaya.

Chong, V. K. dan K. M. Chong. 2002. Budget Goal Commitment and Informational Effects of Budget Participation on Performance: A Structural Equation Modeling Approach. Behavioral Research In Accounting 14: 65-86.

Coryanata, I. 2004. Pelimpahan Wewenang dan Komitmen Organisasi dalam Hubungan antara Partisipasi Penyusunan Anggaran dan Kinerja Manajerial. Makalah Simposium Nasional Akuntansi VII Denpasar: 616-632.

Ghozali, I. 2011. Aplikasi Analisis Multivariate dengan Program SPSS 19. Edisi 5. Penerbit Universitas Diponegoro. Semarang.

Govindarajan, V. dan R. N. Anthony .2007. Management Control Systems. $12^{\text {th }}$ ed. McGraw-Hill International Edition. Boston.

Gul, F. A., J. S. L. Tsui., S. C. C. Fong dan H. Y. L. Kwok. 1995. Decentralisation as a Moderating Factor in the Budgetary Participation-Performance Relationship: Some Hongkong Evidence. Accounting and Business Research 25(98): 107-113.

Himawan, A. K. dan A. Ika S. 2010. Pengaruh Komitmen Organisasi, Gaya Kepemimpinan dan Job Relevant Information (JRI) terhadap Hubungan antara Partisipasi Anggaran dan Kinerja 
Manajerial. Jurnal Ekonomi dan Bisnis 5(9): 65-79.

Indarto, S. L. dan S. D. Ayu 2011. Pengaruh Partisipasi dalam Penyusunan Anggaran terhadap Kinerja Manajerial Perusahaan Melalui Kecukupan Anggaran, Komitmen Organisasi, Komitmen Tujuan Anggaran dan Job Relevant Information. Seri Kajian Ilmiah 14(1): 1-44.

Kren, L. 1992. Budgetary Participation and Managerial Performance: The Impact of Information and Environmental Volatility. The Accounting Review 67(3): 511-526.

Marsudi, S. A. dan I. Ghozali. 2001. Pengaruh Partisipasi Penganggaran, Job Relevant Information (JRI) dan Volatilitas Lingkungan Terhadap Kinerja Manajerial. Jurnal Akuntansi dan Auditing Indonesia 5(2): 101-120.

McGill, R. 2001. Performance Budgeting. The International Journal of Public Sector Management 14(5): 376-390.

Mulyasari, W. dan S. Sugiri. 2004. Pengaruh Keadilan Persepsian, Komitmen pada Tujuan, dan Job Relevant Information terhadap hubungan antara Penganggaran Partisipatif dan Kinerja Manajer. Simposium Nasional Akuntansi VII Denpasar: 439-462

Nor, W. 2007. Desentralisasi Gaya Kepemimpinan Sebagai Variabel Moderating Dalam Hubungan antara Partisipasi Penyusunan Anggaran dan Kinerja Manajerial. Makalah Simposium Nasional Akuntansi X Makassar: 1-27.

Otley, D. 1999. Performance Management: A Framework for Management Control System Research. Management Accounting Research 10: 363-382.

Puspaningsih, A. 2002. Pengaruh Partisipasi Dalam Penyusunan Anggaran Terhadap Kepuasan Kerja dan Kinerja Manajer. Jurnal Akuntansi dan Auditing Indonesia 6(2): 65-79.
Riduwan dan E. A. Kuncoro. 2012. Cara Menggunakan dan Memaknai Analisis Jalur. Cetakan 4. Penerbit Alfabeta. Bandung.

Rihardjo, I. B. 2009. Pengaruh desentralisasi dan komitmen organisasional terhadap hubungan antara penganggaran partisipatif dan kinerja manjerial. Jurnal Ekuitas 13(3): 326-348.

Riyadi, S. 2007. Pengaruh Desentralisasi, Motivasi dan Partisipasi Anggaran Terhadap Kinerja Manajerial Pada Perusahaan Manufaktur Yang Terdaftar Di Bursa Efek Jakarta. Majalah Ekonomi 17(2): 157-180.

Rosidi. 2000. Partisipasi dalam Penganggaran dan Prestasi Manajer: Pengaruh Komitmen Organisasi dan Informasi Job Relevant. Jurnal Ekonomi dan Manajemen 1(1): 1-15.

Sardjito, B. dan O. Muthaher. 2007. Pengaruh Partisipasi Penyusunan Anggaran Terhadap Kinerja Aparat Pemerintah Daerah: Budaya Organisasi dan Komitmen Organisasi Sebagai Variabel Moderating. Prosiding Simposium Nasional Akuntansi X Makassar:124.

Yusfaningrum dan I. Ghozali 2005. Analisis Pengaruh Partisipasi Anggaran terhadap Kinerja Manajerial Melalui Komitmen Tujuan Anggaran dan Job Relevant Information sebagai Variabel Intervening. Prosiding Simposium Nasional Akuntansi VIII Solo: 656-666.

Wentzel, K. 2002. The Influence of Fairness Perceptions and Goal Commitment on Managers' Performance in a Budget Setting. Behavioral Research in Accounting 14: 247-271.

Wirjono, E. R. dan A. B. Raharjono. 2007. Pengaruh Karakteristik Personalitas Manajer terhadap Hubungan antara Partisipasi dalam Penyusunan Anggaran dengan Kinerja Manajerial. Jurnal Kinerja 11(1): 50-63. 